\title{
DESICCATION TOLERANCE AND DNA INTEGRITY IN Eugenia pleurantha O. Berg. (MYRTACEAE) SEEDS ${ }^{1}$
}

\author{
TATHIANA ELISA MASETTO², JOSÉ MARCIO ROCHA FARIA ${ }^{3}$, ANTONIO CLAUDIO DAVIDE ${ }^{4}$ EDVALDO APARECIDO AMARAL DA \\ SILVA 4 .
}

\begin{abstract}
The aim of this study was to assess the desiccation tolerance and DNA integrity in Eugenia pleurantha seeds dehydrated to different moisture contents (MCs). Seeds extracted from mature fruits were dried in silica gel and evaluated at every five percentual points of decrease from the initial MC (35.5\%, fresh weight basis). The effects of dehydration on seeds were verified through germination tests and DNA integrity assessment. Undried seeds achieved $87 \%$ germination, value reduced to $36 \%$ after being dried to $9.8 \% \mathrm{MC}$. When dried slightly more, to $7.4 \% \mathrm{MC}$, seeds were no longer able to germinate, suggesting an intermediate behavior in relation to desiccation tolerance. DNA degradation was observed in seeds with 7.4\% MC, which might have contributed to the loss of seed germination.
\end{abstract}

Index terms: forestry seeds, DNA degradation.

\section{TOLERÂNCIA À DESSECAÇÃO E INTEGRIDADE DO DNA EM SEMENTES DE Eugenia pleurantha O. Berg. (MYRTACEAE)}

\begin{abstract}
RESUMO - Este estudo teve como objetivo avaliar a tolerância à dessecação e a integridade do DNA em sementes de Eugenia pleurantha submetidas a secagem até atingir diferentes graus de umidade. Sementes extraídas de frutos maduros foram submetidas a secagem em sílica gel, sendo avaliadas após cada decréscimo de cinco pontos percentuais a partir do grau de umidade inicial (35,5\%, base úmida). Os efeitos da desidratação foram verificados por meio de testes de germinação e da integridade do DNA. Sementes não submetidas à dessecação apresentaram $87 \%$ de germinação, valor reduzido para $36 \%$ após secagem até $9,8 \%$ de água. Com a redução do grau de umidade para 7,4\%, as sementes não mais germinaram, sugerindo um comportamento intermediário quanto à tolerância à dessecação. Sementes com 7,4\% de água apresentam degradação do DNA, o que pode contribuir para a perda da capacidade de germinação.
\end{abstract}

Termos para indexação: sementes florestais, degradação do DNA.

${ }^{1}$ Submetido em 05/09/2007. Aceito para publicação em 15/01/2008.Parte da dissertação de mestrado do primeiro autor apresentada à Universidade Federal de Lavras (UFLA). ${ }^{2}$ Eng. Agrônoma, Msc. Doutoranda em
Engenharia Florestal - UFLA, CEP37200-000. Lavras, MG. tmasetto@ gmail.com. ${ }^{3}$ Eng. Florestal, Dr. Prof. - UFLA, 372000-000. Lavras, MG. ${ }^{4}$ Eng. Agrônomo, Dr. Prof. - UFLA, 37200-000. Lavras, MG. 


\section{INTRODUCTION}

In the last years there has been an increase in the efforts towards conservation of the genetic variability of plant species, led by the global concern about the continuous environmental degradation. Ex-situ plant conservation in seed banks is recognized as one of the more effective ways to preserve plant diversity (Schoen and Brown, 2001). Plant species produce seeds that behave distinctly in response to the dehydration and storage. Based on these different performances, Roberts (1973) proposed two categories of seeds, to group those that can be dried to very low moisture contents (MCs) and stored for long term periods (orthodox) and those that can neither be drastically dried or stored for the long term (recalcitrant). Later, another category, called intermediate, was introduced by Ellis et al. (1990) to group seeds with intermediate post-harvest behavior. Those seeds are relatively desiccation tolerant, but do not withstand removal of water to levels as low as orthodox seeds. They survive desiccation to about $10 \% \mathrm{MC}$ (fresh weight basis) and can generally be stored for mid-term periods. Such seeds are often chilling sensitive, even in the dehydrated state. Therefore, the difficulty of conservation of the physiological quality of non orthodox seeds has hindered the ex situ conservation of such species in seed banks. In order to develop safe protocols of seed desiccation and storage it is essential to study the behavior of the seeds regarding desiccation tolerance/sensitivity, storability and the intrinsic factors of the desiccation sensitivity.

Eugenia pleurantha O. Berg., a tree species belonging to the Myrtaceae family, is popularly known as "pitanga-domato". It grows in the Brazilian south and southeast regions (Davide et al., 1995) and its seeds were previously classified as recalcitrant (Carvalho, 2000). Other Eugenia tree species also produce recalcitrant seeds (Maluf et al., 2003). Seed research considering this genus is important due to its potential for ecological restoration, since their fresh fruits attract birds and other animals to the recovering area.

A better understanding of the basis of desiccation sensitivity is a prerequisite to proceed toward a long-term storage of non orthodox seeds (Faria et al., 2004). It is known that in dehydrated orthodox seeds the maintenance of DNA integrity and/or the ability for its repair upon rehydration is a fundamental requirement for desiccation tolerance (Pammenter and Berjak, 1999). It is thus reasonable to hypothesize that loss of DNA integrity is one of the causes of viability losses of sensitive seeds subjected to dehydration. For this reason the present study was carried out to characterize the desiccation sensitivity of Eugenia pleurantha seeds and to analyze the DNA integrity during desiccation.

\section{MATERIALS AND METHODS}

The experiment was carried out at the Laboratory of Tree Seeds, Department of Forest Sciences, Federal University of Lavras, Lavras city, Brazil. Ripe fruits were collected from several trees in Lavras $\left(21^{\circ} 14^{\prime} \mathrm{S}, 45^{\circ} 00^{\prime} \mathrm{W}\right)$, located in the south of Minas Gerais State. The climate in the region is classified as $\mathrm{Cwb}$, according to the climatic classification of Köppen (1936), characterized by a dry season (AprilSeptember) and a rainy season (October-March). The annual averages of temperature, rainfall and relative humidity are $19.3^{\circ} \mathrm{C} ; 1411 \mathrm{~mm}$ and $77 \%$ respectively. After collection, part of the fruits was stored for two months in a cold chamber $\left(10^{\circ} \mathrm{C} ; 45 \% \mathrm{RH}\right)$ until the start of the experiments, and the other part was processed immediately. Seed processing was performed according to Davide et al. (1995), consisting of fruit maceration on a sieve, under running water to seed separation from the fruit residues. Seeds were then spread on towel paper over a lab bench and kept for few hours in order to remove the superficial water.

Assessment of the desiccation tolerance: The characterization of the desiccation tolerance of the seeds was done according to Hong and Ellis (1996). Dehydration was done by mixing the seeds with silica gel (fast dehydration) in a closed box at $20^{\circ} \mathrm{C}$, based on Pammenter et al. (1998). Seeds were then weighed at intervals in order to detect the target weights corresponding to the target MCs, according to Cromarty et al. (1985) At approximately every five percentual points of decrease in MC $(30 \%, 25 \%, 20 \%, 15 \%$, $10 \%$ and $5 \%$ ) seeds were sampled for germination tests and MC determination.

Germination tests: were performed in four replications of 25 seeds each on sand in germination boxes, at $30^{\circ} \mathrm{C}$ under continuous white light for 90 days (Masetto, 2005)

Moisture content (MC) determination: was assessed in four replications of $2 \mathrm{~g}$ each, by oven-drying at $103 \pm$ $2^{\circ} \mathrm{C}$ for 17 hours (Brasil, 1992) and expressed as percentage moisture content on a fresh weight basis.

DNA integrity assessment: In order to assess the effect of dehydration on DNA integrity, chromosomal DNA was extracted from five seeds with $35 \%, 30 \%, 20 \%, 10 \%$ and $7 \%$ MC. DNA extraction was performed by using the $\mathrm{CTAB}$ protocol, as follows: samples were ground to powder in liquid nitrogen and transferred to a $2 \mathrm{~mL}$ microtube. It was added $800 \mu \mathrm{L}$ CTAB $2 \mathrm{X}$ and $2 \% \beta$-mercaptoethanol pre-warmed 
to $65^{\circ} \mathrm{C}$, keeping the tube at this temperature for 40 minutes. Next, $800 \mu \mathrm{L}$ chlorophorm-isoamyl alcohol (24:1) was added and the microtubes were inverted for 5 minutes and centrifuged at $7900 \mathrm{rpm}$ for 10 minutes at room temperature. Supernatant was transferred to a new microtube and $2 \mu \mathrm{L}$ RNAase $(10 \mathrm{mg} / \mathrm{mL})$ was added, keeping at $37^{\circ} \mathrm{C}$ for one hour. After, it was added 1 volume of cold isopropanol and the tubes were kept at $-20^{\circ} \mathrm{C}$ for 12 hours. Next, tubes were centrifuged at $14000 \mathrm{rpm}$ at $4^{\circ} \mathrm{C}$ for 10 minutes and supernatant was discharged. It was added $800 \mu \mathrm{L}$ of ethanol $70 \%$ and, after 10 minutes, the tubes were again centrifuged at $7900 \mathrm{rpm}$ at $4^{\circ} \mathrm{C}$ for 10 minutes in order to remove residues of CTAB. Tubes were then inverted in a filter paper to dry the pellet, which was then dissolved in $10 \mu \mathrm{L} \mathrm{TE} \mathrm{pH}$ 8.0 (10mM TRIS-HCl and 1mM EDTA). For comparison purposes, desiccation tolerant (orthodox) seeds of guava (Psidium guajava - Myrtaceae) were used. Ripe fruits of guava were harvested from several trees at the campus of the Federal University of Lavras. DNA was extracted from $1 \mathrm{~g}$ seeds freshly harvested (23.2\% MC) and from $1 \mathrm{~g}$ dried seeds $(7 \%$ MC), dehydrated as described above. Samples of
DNA were loaded on a $1 \%$ agarose gel stained with ethidium bromide and electrophoresed (Faria et al., 2005).

\section{RESULTS AND DISCUSSION}

The freshly harvested seeds of Eugenia pleurantha, with $35.5 \% \mathrm{MC}$ attained only $20 \%$ germination, values close to those found by Carvalho (2000) for the same species (47.1\% initial MC and $25 \%$ germination). In the present study, part of the fruits was stored for two months and, after that, seed germination increased to $87 \%$, which can be attributed to the continuation of seed development within the fruits, since embryos of Eugenia are conferruminate, without a hypocotylradicle axis vestige, suggesting the absence of meristematic tissues differentiated (Barroso, 1999). This, according to Baskin and Baskin (1998), is a type of morphological dormancy.

Dehydration caused accentuated decreases ingermination percentage (normal seedling formation) (Figure 1), pointing that Eugenia pleurantha seeds are desiccation sensitive.

\section{FIGURE 1. Dehydration time course (A) and germination (normal seedlings) of Eugenia pleurantha seeds with different moisture contents $(B)$.}

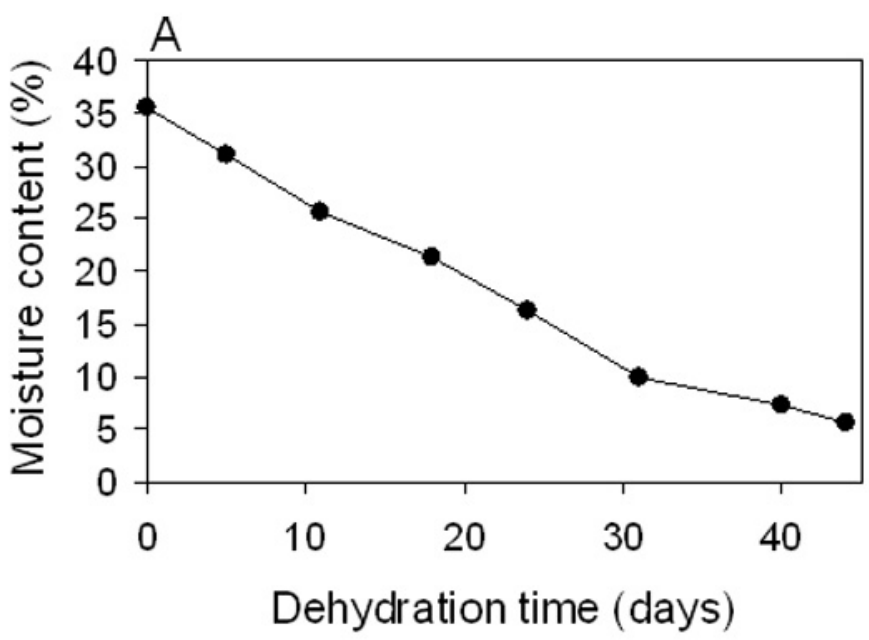

From the results obtained, it is possible to emphasize that germination percentage was maximum when the seed MC was higher than $30 \%$. When MC decreased to values below $25 \%$, seed germination was gradually reduced until being completely lost when MC reached values below $10 \%$.

The drastic reduction of germination when seeds

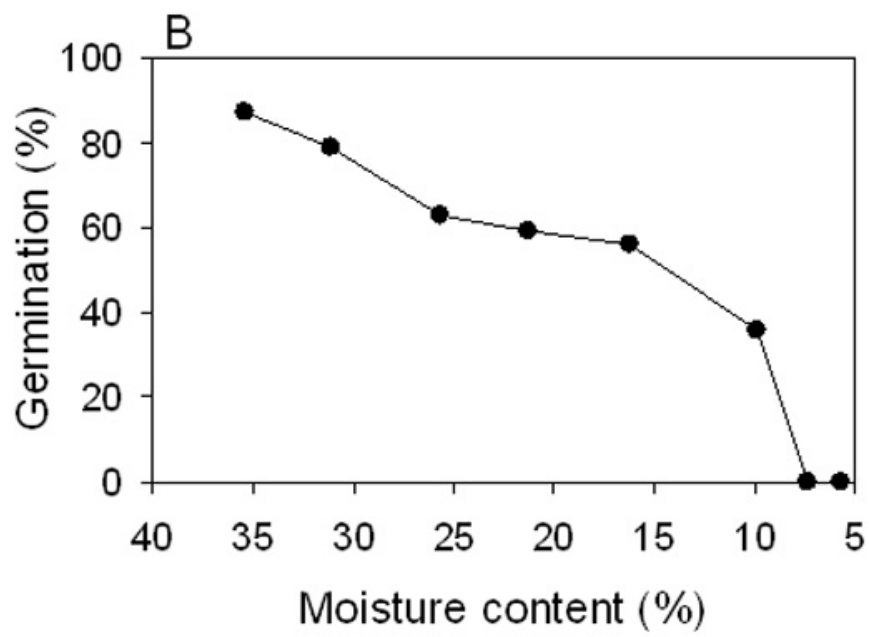

were dried below $10 \% \mathrm{MC}$ suggests that this seeds can be classified as intermediate, since according to Hong and Ellis (1996), intermediate seeds can be safely dried at MC levels about $7-12 \%$.

Carvalho (2000) classified Eugenia pleurantha seeds as recalcitrant, reporting that the freshly harvested seeds $(47.1 \%$ 
MC) attained $25 \%$ of germination and that after dehydration to $11.5 \%$ they completely lost viability. The author also observed that storage of both undried and dried seeds at low temperatures $\left(5^{\circ} \mathrm{C}\right.$ and $\left.-18^{\circ} \mathrm{C}\right)$ was also lethal to the seeds. The difference between the results found by Carvalho (2000) and the present results might be because in the first case, seeds were dried right after collection, when the tissues were still undifferentiated (Barroso, 1999), while in the present study, fruits were stored for 2 months before processing and seed dehydration, which can have allowed seeds to complete differentiation and decrease their desiccation sensitivity. It is known that in a same species, immature seeds are more sensitive to desiccation than the mature ones (Berjak et al., 1992, 1993; Faria et al., 2004). Furthermore, in the work done by Carvalho (2000), the dehydration time was much longer (112 days) than in the present study (44 days). It is known that, for most species that bear desiccation-sensitive seeds, the faster the desiccation rate, the lower the MC that can be reached before viability is totally lost (Pammenter and Berjak, 1999).

The damages caused by dehydration are attributed to the lack or inefficiency of the processes and mechanisms that protect the tolerant seeds in the dehydrated state, such as cellular physical characteristics, intracellular dedifferentiation, the presence of antioxidants systems, accumulation of protecting molecules as LEA proteins, sucrose and other oligosaccharides, deployment of certain amphipatic molecules and the presence and operation of repair mechanisms during rehydration (Pammenter and Berjak, 1999). So, the desiccation sensitivity is associated to the absence or inefficiency of at least one of those processes that facilitate the acquisition and maintenance of desiccation tolerance in orthodox seeds. In desiccation sensitivity seeds, the loss of structural water during dehydration process causes alteration of metabolic and membranes systems, resulting in seed deterioration (Farrant et al., 1988). Theoretically, the desiccation tolerance tends to increase with the number of protection mechanisms in activity (Berjak and Pammenter, 2000).

Many Eugenia species bear non-orthodox seeds, such as E. florida and E. rostrifolia, classified as intermediate by Carvalho (2000) and Santos et al. (2004), respectively, and the following, classified as recalcitrant: E. calycina (Bülow et al., 1994), E. pyriformis (Andrade and Ferreira, 2000; Silva et al., 2003), E. brasiliensis (Andrade, 2002), E. involucrata (Maluf et al., 2003), E. divaricata (Gentil, 2003), E. dysenterica, E. unifolia and E. bimarginata (Faiad et al., 2005).

The germination percentages of guava seeds were $81 \%$ (freshly harvested seeds; $23.2 \% \mathrm{MC}$ ) and 90\% (seeds dried to $7 \% \mathrm{MC}$ ). It is possible to observe that the DNA isolated from guava seeds kept its integrity after dehydration, as shown by the single strong band (lanes 1 and 2 in Figure 2). In orthodox seeds such ability certainly is related to the mechanisms of cell survival under decreased hydration level. The same was verified in DNA of E. pleurantha embryos with $30 \%, 20 \%$ and $10 \% \mathrm{MC}$ (Figure 2), although presenting a constant reduction of the germination percentages (Figure 1B). DNA isolated from E. pleurantha embryos dried to $7 \%$ MC appeared highly degraded as shown by the smeared

FIGURE 2. Agarose gel of genomic DNA extracted from guava (Psidium guajava) seeds (lanes 1 and 2) and Eugenia

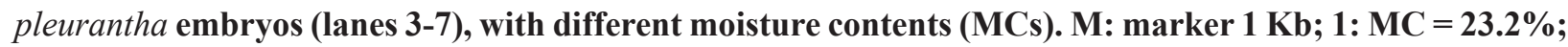
$2: M C=7.0 \% ; 3: M C=35.5 \% ; 4: M C=30.0 \% ; 5: M C=20.0 \% ; 6: M C=10 \% ; 7: M C=7 \%$.

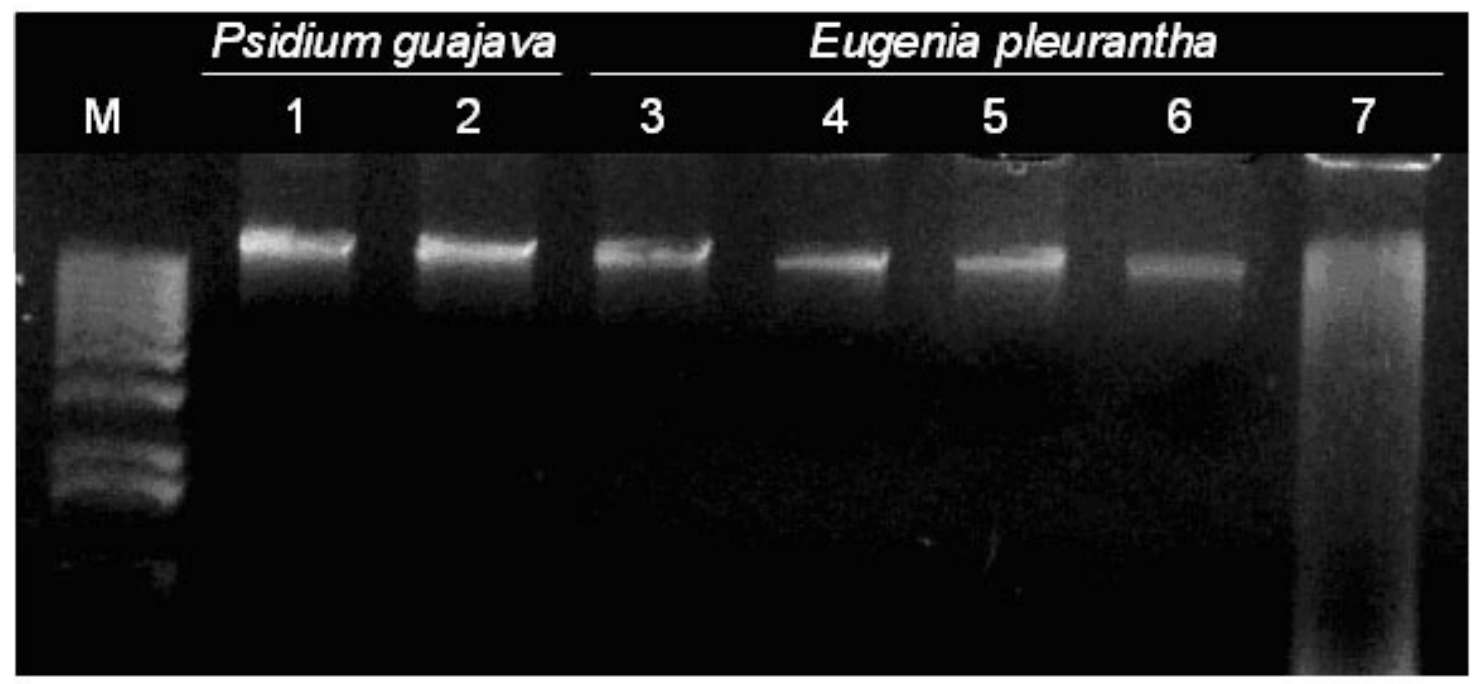


band (lane 7, Figure 2), coinciding with the total loss of seed germinability (Figure 1B).

The degradation pattern observed is due to the passive cell death process (Wang et al., 1998), which is triggered when the cells are subject to environmental stress. Faria et al. (2005) also related DNA fragmentation in radicles of germinated seeds of Medicago truncatula submitted to dehydration..

Seed MC is associated to the maintenance of proteins integrity, endonucleases activation and DNA conformation (Osborne, 2000). In the dehydrated state, protein denaturation, membrane damages, loss of enzymes function and nucleic acids integrity occur at rates influenced both by the environmental conditions and genotype (Osborne and Boubriak, 1997). Since seed desiccation tolerance is genetically controlled, it is thought that in intermediate seeds, a combination of genes provides considerable but incomplete desiccation tolerance (Hong and Ellis, 1995).

The maintenance of genetic information is an essential requirement for desiccation tolerance and cell survival after the dehydration and rehydration (Osborne et al. 2002). Cell DNA damages take place if dehydration occurs when chromatin or DNA conformation are not organized to support dehydration (Osborne and Boubriak, 1994). In the present study, the reduction of the MC of E. pleurantha seeds to $7 \%$ caused DNA degradation in a possibly irreversible way, leading to the loss of its functional condition and consequent seed death.

\section{CONCLUSIONS}

When subjected to dehydration, seeds of Eugenia pleurantha reacted in a way that suggests an intermediate behavior in relation to desiccation tolerance.

The loss of DNA integrity can be counted as one of the causes of loss of viability in E. pleurantha seeds dehydrated to $7 \%$ moisture content.

\section{REFERENCES}

ANDRADE, R.N.B.; FERREIRA, A.G. Germinação e armazenamento de sementes de uvaia (Eugenia pyriformis Cambess.-Myrtaceae). Revista Brasileira de Sementes, Pelotas, v.22, n.2, p.118-125, 2000.

ANDRADE, R.N.B. Germinação de sementes de plantas ornamentais ocorrentes no Rio Grande do Sul. 2002. 110 f. Tese (Doutorado) - Universidade Federal do Rio Grande do Sul, Porto Alegre.
BARROSO, G.M.; MORIM, M.P.; PEIXOTO, A.L.; ICHASO, C.L.F. Frutos e sementes: morfologia aplicada à sistemática de dicotiledôneas. Viçosa: UFV, 1999. 443 p.

BASKIN, C.C.; BASKIN, J.M. Seeds - ecology, biogeography and evolution of dormancy and germination. New York: Academic Press, 1998. p.5-26.

BERJAK, P., PAMMENTER, N.W.; VERTUCCI, C. Homoiohydrous (recalcitrant) seeds: developmental status, desiccation sensitivity and the state of water of Landolphia kirkii Dyer. Planta, Berlin, v. 186, p. 249-261, 1992.

BERJAK, P., VERTUCCI, C.W. and PAMMENTER, N.W. Effects of developmental status and dehydration rate on characteristics of water and desiccation-sensitivity in recalcitrant seeds of Camellia sinensis. Seed Science Research, Wallingford, v. 3, p. 155-166, 1993.

BERJAK, P.; PAMMENTER, N.W. What ultrastructure has told us about recalcitrant seeds. Revista Brasileira de Fisiologia Vegetal, v.12, p.22-55, 2000.

BRASIL. Ministério da Agricultura. Regras para análise de sementes. Brasília, DF, 1992. 365p.

BÜLOW, J.F.W.V.; CARMONA, R.; PARENTE, T.V. Armazenamento e tratamento de sementes de pitangavermelha-do-cerrado (Eugenia calycina). Pesquisa Agropecuária Brasileira, Brasília, v.29, n.6, p.961-970, 1994.

CARVALHO, L.R. Classificação fisiológica de sementes de espécies florestais quanto à capacidade de armazenamento. 2000. 97 f. Dissertação (Mestrado em Engenharia Florestal) - Universidade Federal de Lavras, Lavras.

CROMARTY, A.S.; ELLIS, R.H.; ROBERTS, E.H. Designing of seed storage facilities for genetic conservation. Rome: IPGRI, 1985. 100p.

DAVIDE, A.C.; FARIA, J.M.R.; BOTELHO, S.A. Propagação de espécies florestais. Belo Horizonte: CEMIG/ UFLA/FAEPE; Lavras: UFLA, 1995. 41p.

ELLIS, R.H.; HONG, T.D.; ROBERTS, H. An intermediate category of seed storage behaviour? I. Coffee. Journal of Experimental Botany, London, v.41, n.230, p.1167-1174, 1990.

FAIAD, M.G.R.; SALOMÃO, A.N.; SANTOS, I.R.I. Estratégias e resultados da conservação de germoplasma-semente a longo prazo. Disponível em http://www.ambientebrasil.com.br/ composer.php3?base=./ biotecnologia/index.html\&conteudo=./biotecnologia/ artigos/germoplasma.html . Acesso em: 30 nov. 2005.

FARIA, J.M.R.; van LAMMEREN, A.A.M.; HILHORST, 
H.W.M. Desiccation sensitivity and cell cycle aspects in seeds of Inga vera subsp. affinis. Seed Science Research, Wallingford, v. 14, p. 165-178, 2004.

FARIA, J.M.R.; BUITINK, J.; van LAMMEREN, A.A.M.; HILHORST, H.W.M. Changes in DNA and microtubules during loss and re-establishment of desiccation-tolerance in germinating Medicago truncatula seeds. Journal of Experimental Botany, Oxford, v.56, p.2119-2130, 2005.

FARRANT, J.M.; PAMMENTER, N.W.; BERJAK, P. Recalcitrance; a current assessment. Seed Science and Technology, Zurich, v.16, p.155-166, 1988.

GENTIL, D.F.O. Conservação de sementes de Myrciaria dubia (H.B.K.) McVaugh. 2003. 41 f. Tese (Doutorado em Agronomia) - Escola Superior de Agricultura "Luiz de Queiroz”, Piracicaba.

HONG, T.D.; ELLIS, R.H. Interspecific variation in seed storage behaviour within two genera - Coffea and Citrus. Seed Science and Technology, Zurich, v.23, p.165-181, 1995.

HONG, T.D.; ELLIS, R.H. A protocol to determine seed storage behaviour. Rome: International Plant Genetic Resources Institute, 1996. 55p (IPGRI. Technical Bulletin, 1)

KÖPPEN, W. Das geographische system der klimate. In: KÖPPEN, W.; GEIGER, R. (Ed.). Handbuch der klimatologie 3, Berlin: Gebrüder Borntraeger, 1936.

MALUF, A.M.; BÍLIA, D.A.; BARBEDO, C.J. Drying and storage of Eugenia involucrata DC. seeds. Scientia Agricola, Piracicaba, v.60, n.3, p.471-475, 2003.

MASETTO, T.E. Estudo da sensibilidade à dessecação em sementes de Eugenia handroana D. Legrand (Myrtaceae), 2005. 60f. Dissertação (Mestrado em Engenharia Florestal) - Universidade Federal de Lavras, Lavras.

OSBORNE, D.J. Hazards of a germinating seed: available water and the maintenance of genomic integrity. Israel Journal of Plant Sciences, Wallingford, v.48, p. 173-179, 2000.

OSBORNE, D.J.; BOUBRIAK, I.I. DNA and desiccation tolerance. Seed Science Research, v.4, p 175-185, 1994.
OSBORNE, D.J.; BOUBRIAK, I.I. DNA status, replication and repair in desiccation tolerance and germination. In: ELLIS, R H.: BLACK, M.; MURDOCH, A. J.; HONG, T. D. (Ed).). Basic and applied aspects of seed biology. Dordrecht: Kluwer Academic, 1997. p.23-32. (Current Plant Sciences and Biotechnology in Agriculture, 30). Proceedings of the Fifth International Workshop on Seeds, Reading, 1995.

OSBORNE, D.J.; BOUBRIAK, I.; LEPRINCE, O. Rehydration of dried systems: membranes and nuclear genome. In: BLACK, M.; PRITCHARD, H.W. (Ed.). Desiccation and survival in plants: drying without dying. Wallingford: CABI Publishing, 2002. p.343-364.

PAMMENTER, N.W.; GREGGAINS V.; KIOKO, J.I.; WESLEY-SMITH, J.; BERJAK, P.; FINCH-SAVAGE, W.E. Effects of differential drying rates on viability of recalcitrants seeds of Ekebergia capensis. Seed Science Research, Wallingford, v.8, p. 463-471, 1998.

PAMMENTER, N.W.; BERJAK, P. A review of recalcitrant seed physiology in relation to desiccation-tolerance mechanisms. Seed Science Research, Wallingford, v.9, p.13-37, 1999.

ROBERTS, E.H. Predicting the storage life of seeds. Seed Science and Technology, Zurick, v.1, n.4, p.449-514, 1973.

SCHOEN, D.J.; BROWN, A.H.D. The conservation of wild plant species in seeds banks. Bioscience, Wallingford, v.51, n.11, p.960-966, 2001.

SANTOS, C.M.R.; FERREIRA, A.G.; ÁQUILA, M.E.A. Características de frutos e germinação de seis espécies de Myrtaceae nativas do Rio Grande do Sul. Ciência Florestal, Santa Maria, v.14, n.2, p.13-20, 2004.

SILVA, C.V.; BILIA, D.A.C.; MALUF, A.M.; BARBEDO, C.J. Fracionamento e germinação de sementes de uvaia (Eugenia pyriformis Cambess.-Myrtaceae) Revista Brasileira de Botânica, São Paulo, v.26, n.2, p.213-221, 2003.

WANG, M.; OPPEDIJK, B.J.; CASPERS, M.P.M.; LAMERS, G.E.M.; BOOT, M.J.; GEERLINGS, D.N.G.; BAKHUIZEN, B.; MEIJER, A. H.; VAN DUIJN, B. Spatial and temporal regulation of DNA fragmentation in the aleurone of germination barley. Journal of Experimental Botany, Oxford, v.49, p.1293-1301, 1998. 